\title{
Preliminary study of algasidal activities of the episymbiont bacterial consortium from Enhalus acoroides
}

\author{
Gede Iwan Setiabudi ${ }^{1}$, Ocky Karna Radjasa ${ }^{3}$, Dietriech G. Bengen ${ }^{2}$, and Hefni Effendi ${ }^{2}$ \\ ${ }^{1}$ Lecturer on Departement of Fishery and Marine Science Ganesha Education University \\ ${ }^{2}$ Lecturer on Fisheries and Marine Science Faculty of Bogor Agricultural University \\ ${ }^{3}$ Lecturer on Fisheries and Marine Science Faculty of Diponegoro University \\ *Correspondence author: insetiabudi@gmail.com
}

\begin{abstract}
Seagrass symbiotic bacteria have various functions, one of which is as algaside. There are 2 types of symbionts namely endosymbiont and episymbiont. This study aims to test the initial activity of algaside episymbiont Enhalus acoroides on diatome and dinoflagellate group plankton. The method used for testing is Mixed Algal-bacterial cultures. On media that has been overgrown with algae will be inoculated with episymbiont bacterial consortium E. acoroides. The results of the bacterial consortium research have not shown significant algaside activity. But, on Nitschia sp. showed significant algaside activity. This mean specific activity in the compound or mechanism used as algaside.
\end{abstract}

Keywords: Algaside, episymbiont, Enhalus acoroides, bacterial consortium, seagrass

\section{INTRODUCTION}

Seagrass leaf epidermis is a good place for the growth of various types of epiphytes. The structure serves to exchange gas and nutrients produced by photosynthesis and osmoregulation. Seagrasses remove $2 \%$ of photosynthesis in the form of DOC. These compounds cause an increase in the bacterial population in seagrass leaves. It is known that as epiphytic bacteria have a complex role in microzone seagrass leaves, pioneers, plankton interactors, form biofilms, regulate microtopography and micro-chemical surface of microzone [1, 2].

Potential diversity and number of seagrass episimbion with large leaf cross-sectional is higher than the small cross-sectional area. In Enhalus acoroides the epiphytic cover reaches $12.2 \%$ of the total leaf area, compared to Thalassia hemprichii which is only $1.9 \%$ [3]. There are not many epiphytes in $T$. hemprichii and changes in the symbion composition of these species are influenced by phosphate variability [4]. In the seagrass Halophila stipulacea bacteria are found in the tips of the leaves, while the base of the leaves is very little [5].

Research shows high seagrass episimbion bacteria diversity. The bacteria found as epiphytes in seagrass are Vibrio, Alteromonas, Moraxella, Pseudomonas, Marinobacter, Brochotrix and nitrogen fixation bacteria [6, 5]. Researcher [7] successfully isolated 110 actinobacteria that could be cultured from T. hemprichii. These were isolated from Nancun Port China waters. Various types of bacteria can live as episimbions in seagrasses that have diverse functions. Researcher [8] succeeded in isolating $T$. hemprihii symbiont bacteria capable of producing Diadinosanthine carotinoid pigments (cis, trans chains and isomers). These pigments can be used in cosmetics and vitamin A precursors. Researcher [9] succeeded in isolating biofilm-forming bacteria in $\mathrm{H}$. pinifolia species. Researcher [10] also managed to isolate episimbion bacteria from seagrasses that have the ability as antifouling.

Researcher [11] stated that there is a symbiosis between seagrasses, bivalves and bacteria capable of reducing sulfite from the environment. Symbiotic bacteria play a role in the dynamics of seagrass development and the taking of various types of nutrients such as carbon, nitrogen and phosphorus from the environment [12]. Researcher [13] found that seagrass extracts of Zostera oceanica and $Z$. noltii were able to inhibit the growth of Alexandrium catenella. Researcher [14] extracting larvicidal compounds from their roots which can kill mosquito larvae from dengue fever vector. Researcher [15] has found episimbion bacteria in Z. marina which has strong algaside ability. Researcher [16] has found Bacillus $\mathrm{sp}$. isolated from seagrass has the ability as an antifouling.

Based on various facts that have been explained, episimbion E. acoroides has various potential to be developed. One potential that can be explored is as a new source of algasida. So this study tried to isolate the consortium of seagrass species symbion bacteria and test their algasidal activity.

\section{RESEARCH METHOD}

Sampling and isolation of the seagrass bacteria

$E$. acoroides samples were taken from Teluk Pegametan, Buleleng, Bali. Episimbion isolation using the method used by [17]. E. acoroides leaves which are free from macroepifit are taken about $5 \mathrm{~cm}$. The sample is then put in a plastic bag and placed in a cooling container for further transport to the laboratory. The samples were then sprayed with sterilized seawater three times to get a biofilm then carried out with sterile scraping tools. The results of scraping are put into $10 \mathrm{~mL}$ of sterile sea water and diluted to obtain dilution of $10^{-1}, 10^{-2}$ and $10^{-3}$. From the $10^{-3}$ dilution level, $100 \mu \mathrm{l}$ was taken with a pipette, put into the prepared ZoBell 2216E marine broth in a test tube. 
The episymbiont bacterial consortium isolate is then given the EhEp code.

\section{Incubation of plankton}

The monoculture algae that were tested were obtained from the P2O LIPI algaeCulture Laboratory. The species tested were two groups of algae, dinoflagelates and diatoms. The dinoflagellate group consists of Porphyridium sp. and BG (algae isolated in Jakarta Bay during 2015 algae blooms and have not been identified). The diatom group consisted of Nitzschia sp., Chaetoceros sp., Navicula sp. and Thalassiosira sp. Its growth uses Daigo's (Nihon Pharmaceutical Co., Ltd) IMK media at room temperature $\left(28^{\circ}-30^{\circ} \mathrm{C}\right)$. Especially for diatom groups added silicate, with a concentration of $1 \mathrm{~mL} . \mathrm{L}^{-1}$ media. The culture was incubated for 2-3 days until it reached a density of $\pm 102-104$ cells. $\mathrm{mL}^{-1}$. The testing activity uses a plaque bottle with a maximum volume of $35 \mathrm{~mL}$. Test culture volume with a bacterial consortium of $30 \mathrm{~mL}$. During the test also accompanied by control, as a visual comparison of the state of culture and growth of plankton.

\section{Algasidal activities test}

The method used in algaside testing is Mixed Algalbacterial cultures [18]. The two consortiums were then added $0.6 \mathrm{~mL}(2 \%)$ each to $30 \mathrm{~mL}$ of target algae culture. Repetition of treatment three times, plus one control. Then incubated for 24 hours in a shaker incubator with a radiation period of $12: 12$, at room temperature $28^{\circ}-30^{\circ} \mathrm{C}$. After incubation in the span of time, observations of the amount of algae were used using MPC-200 Plankton Counter preparations. The observation process continues until the fifth day of incubation. Observations were made under a microscope with x100 magnification.

\section{The Procedure of Data Analysis}

Algacidal activity level of the bacterial consortium was calculated in the form of percentages using the formula proposed by [19]. The statistical test using the tstudent test was used in every treatment to identify the different algacidal activities in the target plankton growth. The formula which was used to identify the level of the algacidal activities are as follows.

$$
\% A A=\left(1-\left(\frac{T t}{C t}\right)\right) \times 100
$$

\section{RESULTS AND DISCUSSION}

Results

Algasida EhEp Activity Level

The level of algae activity can be known by calculating the percentage of treatment algae density compared to controls. Evaluation is done on the last day of observation. Calculation of the percentage of bacterial consortium algaside activity using the equation in [19]. Episymbiont bacteria consortium showed low algaside activity in all target plankton, except Nitzschia sp. and Porphyridium sp (Table 1).

\section{Plankton Morphology}

Plankton growth was tested to be low, except for Nitzschia sp. During the five days of observation of plankton microstructure conditions, there were various symptoms of cell damage that could be recognized from cell deformation and damage to cell components. The cytoplasm is damaged with shrinkage symptoms $>50 \%$ of its original size (Figure 1)

TABEL 1 .

ACTIVITY OF ALGASIDE CONSORTIUM OF EPISYMBIONT BACTERIA FROM Enhalus acoroides ACTIVITY LEVELS ARE EVALUATED ON THE FIFTH DAY

\begin{tabular}{ccccccc}
\hline \multirow{2}{*}{ Treatments } & \multicolumn{5}{c}{ Plankton } \\
\cline { 2 - 6 } & Porphyridium $\mathrm{sp}$. & BG & Nitzschia sp. & Chaetoceros $\mathrm{sp}$. & Navicula sp. & Thalassiosira $\mathrm{sp}$ \\
\hline EhEp $(\%)$ & 37.3 & 14.3 & 20.5 & 7.5 & 13.6 & 5.0 \\
\hline
\end{tabular}
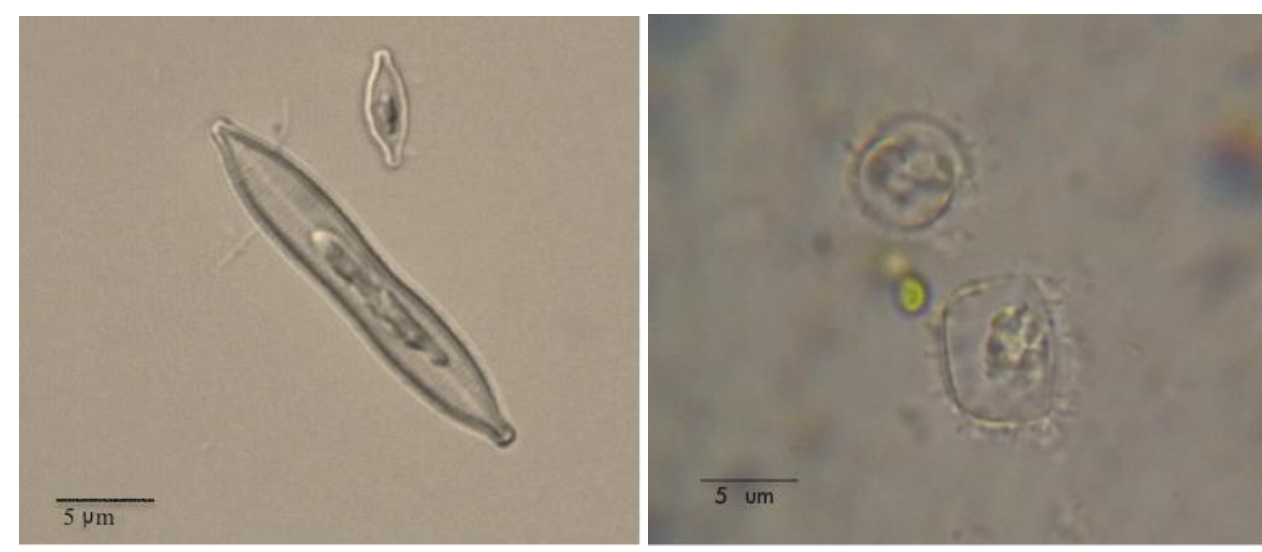

Fig. 1. Cell micrograph of Nitzschia sp. in normal shape (A); cells undergo deformation and shrinkage (B) 
TABEL 2.

RECAPITULATION OF STUDENT T-TEST RESULTS AT THE 5\% LEVEL OF PLANKTON DENSITY CONTROL AND TREATMENT

\begin{tabular}{|c|c|c|c|}
\hline & Porphyridium sp. & $\mathrm{BG}$ & Nitzschia sp. \\
\hline \multirow{3}{*}{$\mathrm{t}$} & EhEp & EhEp & EhEp \\
\hline & $0.065^{\mathrm{ns}}$ & $0.042^{\mathrm{ns}}$ & $0.450^{\mathrm{ns}}$ \\
\hline & Chaetoceros sp. & Navicula sp. & Thalassiosira sp. \\
\hline & EhEp & EhEp & EhEp \\
\hline $\mathrm{t}$ & $0.628^{\mathrm{ns}}$ & $0.856^{\mathrm{ns}}$ & $0.775^{\mathrm{ns}}$ \\
\hline
\end{tabular}

* significantly different between control and treatment

${ }^{n s}$ not significantly different between control and treatment

$[\mathbf{A}]$

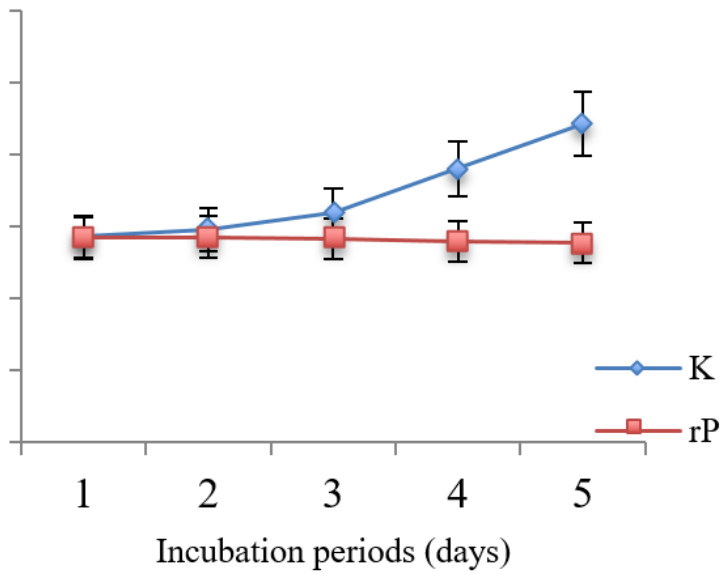

$[\mathbf{B}]$

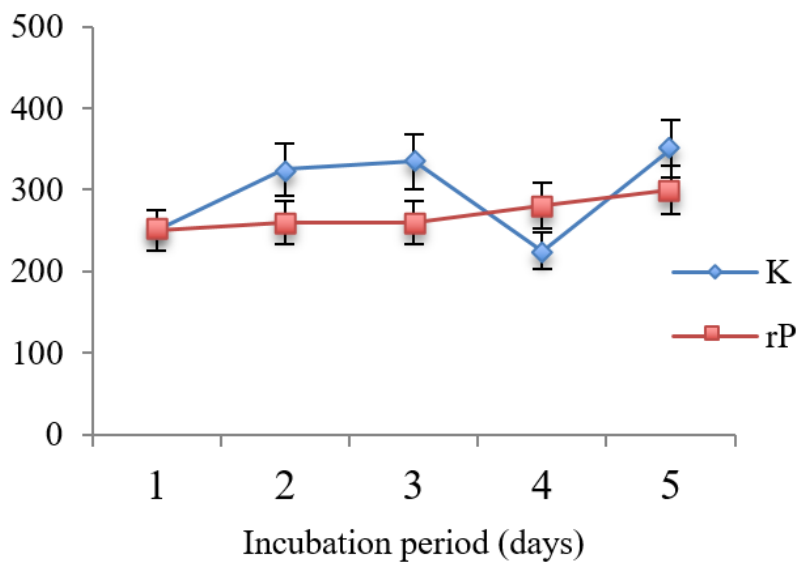

Fig. 2. Dinoflagellates growth control and the treatment with EhEp for five days of observation. Control (K); Treatment with EhEp (rP); Porphyridium sp. with EhEp (A); BG culture with EhEp (B).
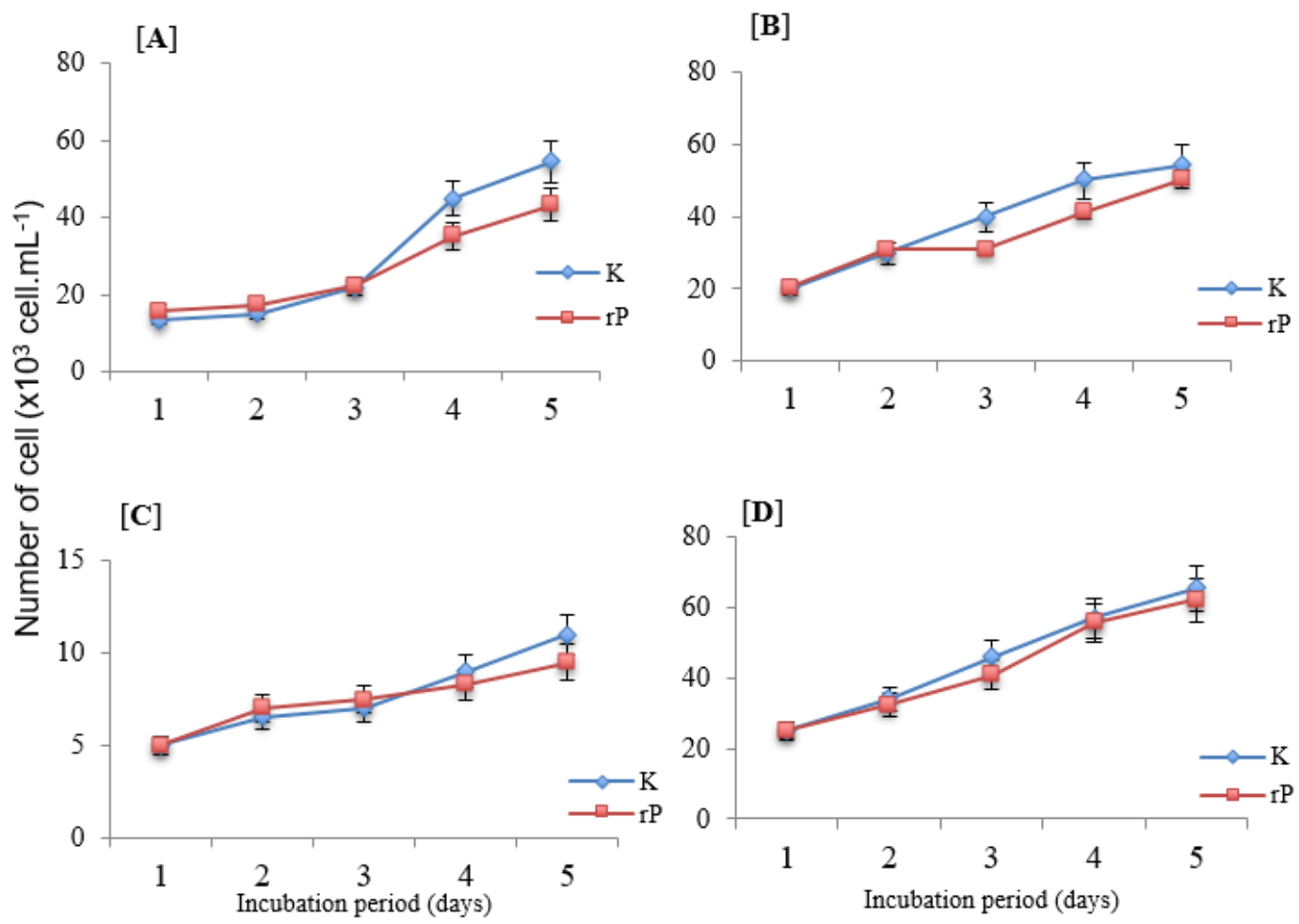

Fig. 3. Diatomes growth control and the treatment with EhEp for five days of observation. Control (K); Treatment with (rP); Nitzschia sp. with EhEp (A); Chaetoceros sp. with EhEp (B); Navicula sp. with EhEp (C); Thalassiosira sp. with EhEp (D). 


\section{Plankton density}

Dinoflagellate density both control and treatment were evaluated daily for five days. Porphyridium sp. Plankton cell density. and the BG treated with EhEp showed a thin increase in density compared to the control (Figure 2). This also occurs with the growth of diatomic plankton groups, the pattern of growth follows control (Figure 3).

\section{Effects of Algasida Activity on Growth}

Student t-test results showed the algaside activity of EhEp episymbiont bacteria had almost no effect on plankton growth. This is indicated by no significant difference between the control and treatment at 5\% significance level, except in Nitzschia sp. The algaside activity shows a significant effect. This means that the episimbion bacteria consortium has no significant effect on the growth of dinoflagellates and diatoms (Tabel 2).

\section{Discussion}

Many bacterial isolates have been known to have the ability as algasides. The source of these isolates are planktonic bacteria. Some even develop along with algae growth explosions. The mechanism is a natural counterweight for the plankton group. Some bacteria that are known to be antagonistic in plankton are Flavobacterium sp. 5N-3 which can inhibit the growth of Gymnodinium sp. Bacillus sp. SY-1 isolated from Masan waters in South Korea was able to suppress the growth of Cochlodinium polykrikoides [20]. Bacterial isolates obtained from Japan's Kagosima Bay Saprospira sp. SS985 is even able to reduce the growth of the diatom group Chaetoceros ceratosporum [21].

Researcher [22] succeeded in isolating $P$. haloplanktis AFMB-08041 from the surface water in Masan Bay, Korea. These bacteria are able to inhibit the growth of Prorocentrum minimum up to $90 \%$ within 5 days. Observations show that plankton is directly attacked by this bacteria. The algalytic compound produced is active beta-glucosidase. Other capabilities of these bacteria can suppress the growth of various species of HABs including Alexandrium tamarense, Akashiwo sanguinea, Cochlodinium polykrikoides, Gymnodinium catenatum, and Heterosigma akashiwo. These bacteria tend to attack plankton with morphology similar to $P$. minimum such as $P$. dentatum. Therefore, the bacteria is prepared to control HABs in the natural environment.

This study uses bacterial isolates from EhEp. In the algaside activity test against Porphyridium sp. and BG (dinoflagelate) found that episymbiont bacteria consortium was less able to inhibit algal growth. The EhEp bacterial consortium showed $<40 \%$, with a five-day inoculation time. The algaside activity was confirmed also by the student t-test results which stated that there was no significant difference in plankton growth density between control and treatment.

EhEp bacterial consortium on Nitzschia sp. showed algaside activity tended to be significant. Its growth density showed an increase from 15,967 cells. $\mathrm{mL}^{-1}$ on the first day to 43,245 cells. $\mathrm{mL}^{-1}$. This number is smaller than the control on the fifth day which reached 54.400 cells.mL

1. The effect of algaside activity on Nitzschia sp. can be observed in cell damage, characterized by cell deformation and cytoplasmic shrinkage. It is also owned by Saprospira sp. SS98-5 was able to reduce the growth of the diatom group Chaetoceros ceratosporum [21].

The Nitzschia genera consists of many species and can live in fresh, brackish and sea waters. The genera has very fast reproductive abilities and can adapt to various environmental conditions. Environmental factors that influence its development are the presence of abundant nutrients, lack of predators, high DO, high temperatures and high light intensity. Some of the species have the ability to produce neurotoxins (domoic acid). In tropical waters its can be very high abundance, if the predator is a little. High abundance can trigger the appearance of species that produce toxins. Researcher [23] succeeded in isolating Nitzschia navis-varingica from Vietnamese waters which had the ability to produce domoic acid.

The Nitzschia genera consists of many species and can live in fresh, brackish and sea waters. The genera has very fast reproductive abilities and can adapt to various environmental conditions. Environmental factors that influence its development are the presence of abundant nutrients, lack of predators, high DO, high temperatures and high light intensity. Even some members of the species have the ability to produce neurotoxins (domoic acid). In tropical waters its abundance can be very high in limited predator conditions. High abundance can trigger the appearance of species that produce toxins. Researcher [23] succeeded in isolating Nitzschia navis-varingica from Vietnamese waters which had the ability to produce domoic acid.

Observations show that plankton trapped by cytoplasmic biofilms shrink. EhEp consortium bacteria can produce secondary metabolites which can seep into plankton cells. This also occurs in diatoms, where cells undergo deformation and the cytoplasm of the cell undergoes shrinkage. Researcher [24] used biosurfactant glycolipid biosurfactant sophorolipid isolated from yeast Turolopsis gabarata as algaside for Alexandrium tamarense, Heterosigma akashiwo and Cochlodinium polykrikoides. These metabolites damage the cytoplasm and lyse cell membranes. Researcher [25] found Streptomyces sp. L74 produces secondary metabolites which can disrupt the mechanism of the microcystis aeruginosa cyanobacter antioxidant. These mechanisms include indirect inhibition by producing secondary metabolites. Researcher [26] found that bacteria capable of suppressing plankton growth have the ability to produce chitinase enzymes. The enzyme can damage the diatom cell wall, so that the diatom undergoes lysis. The destruction of the cell wall is a direct attack mechanism.

\section{CONCLUSION}

The EhEp bacterial consortium showed less significant algaside activity against diatoms and dinoflagellates, except Nitzschia sp. This fact makes the episymbiont of E. acoroides not yet potentially used as a source of algasida. The ability of seagrass bacteria consortium requires further study. The aspects that can be examined are episimbion interaction patterns with other planktonic microorganisms and with the seagrass. 
Ecological aspects that play a role in this interaction pattern can be investigated to find out the influential environmental factors, which require further study. Further things that can be developed are episymbion interaction patterns with other planktonic microorganisms and with the seagrass.

\section{REFERENCES}

[1] Marba N, Holmer M, Gacia E, Barron C. 2006. Seagrass Beds and Coastal Geochemistry. Larkum AWD, Orth RJ, Duarte CM, editor. Seagrass: Biology, Ecology and Conservation. Netherlands: Springer. p. 135-153.

[2] Michael TS, Shin HW, Hanna R, Spafford DC. 2008. A Review of Epiphyte Development: Surface Intercations and Settlement on Seagrass. J Enviro Biol [Internet]. [diunduh 2016 April]; 29(4): 629-638. Tersedia pada: www.jeb.co.in.

[3] Leliaert F, Van-Reusel W, De-Clerck O, Coppejans E. 2001. Epiphyte of Seagrass of Zanzibar Island (Tanzania), Floristic and Ecological Aspect. Belg $J$ Bot. 131(1): 3-20.

[4] Frankovich TA, Fourqurean JW. 1997. Seagrass Epiphyte Loads Along a Nutrient Avaibility Gradient, Florida Bay, USA. Mar Ecol Prog Ser. 159: 37-50.

[5] Borowitzka MA, Lavery PS, van Keulen M. 2006. Epiphyte Seagrasses. Larkum AWD, Orth RJ, Duarte CM, editor. Seagrass: Biology, Ecology and Conservation. Netherlands: Springer. p. 441-456.

[6] Kurilenko VV, Ivanova EP, Mikhailov V. 2001. Zonal Distribution of Epiphytic Microorganism on the Eelgrass Zostera marina. Microbiol. 70(3): 372-373. DOI: 10.1023/A.1010475916224.

[7] Wu H, Chen W, Wang G, Dai S, Zhou D, Zhao H, Guo Y, Ouyang Y, Li X. 2012. Culture-dependent Diversity of Actinobacteria Assosiated with Seagrass (Thalassia hemprichii). Afric J Microbiol Res. 6(1): 87-94. DOI: 10.5897/AJMR11.981.

[8] Nugraheni SA, Khoeri MM, Kusmita L, Widyastuti Y, Radjasa OK. 2010. Characterization of Carotenoid Pigments from Bacterial Symbionts of Seagrass Thalassia hemprichii. J Coast Develop. 14(1): 51-60.

[9] Merina M, Lipton AP, Wesley SG. 2011. Isolation, Characterization and Growth Respon of Biofilm Forming Bacteria Bacillus pumilus from the Seagrass, Halodhule pinifolia off Kanyakumari Coast. Indian J Mar Sci. 40(3): 443-448.

[10] Cho JY, Kang JY, Hong YK, Baek HH, Shin HW, Kim MS. 2012. Isolation and Structural Determintation of Antifouling Diketopiperazines from Marine-derived Streptomyces praecox 291-11. Biosci Biotechnol Biochem. 76(6): 1116-1121. http://dx.doi.org/10.1271/bbb.110943.

[11] van der Heide T, Govers LL, de Fouw J, Olff H, van der Geest M, van Katwijk MM, Piersma T, van de Koppel J, Silliman BR, Smolders AJP, van Gils JA. 2012. A Three-Stage Symbiosis Forms the Foundation of Seagrass Ecosystems. Sci. 336: 1432-1434. DOI: 10.1126/science.1219973.

[12] Garcias-Bonet N, Arrieta JM, de Santana CN, Duarte CM, Marba N. 2012. Endophytic bacterial community of a Mediterranean marine angiosperm (Posidonia oceanica). Front in Microbiol. 3: Article 342.

[13] Laabir M, Grignon-Dubois M, Masseret E, Rezzonico B, Soteras G, Rouquette M, Rieuvilleneuve F, Cecchi P. 2013. Algacidal Effect of Zostera marina L and Zostera noltii Hornem. Extracts on the Neuro-toxic Bloom-forming Dinoflagellate Alexandrium catenella. Aqua Bot. 111: 16-25. http:/dx.doi.org/10.1016/ j.aquabot.213.07.010.

[14] Ali MS, Ravikumar S, Beula JM. 2013. Larvasidal Potential of Seagrass Extracts against Dengue Vector Aedes Aegypty (Insecta: Diptera: Culicidae) [Internet]. Int J Pharm Bio Sci [diunduh 2016 Mei]; 4(2): 62-67. Tersedia pada: www.ijpbs.net.

[15] Imai I. 2015. Interactions Between Harmful Algae and Algicidal and Growth-Inhibiting Bacteria Associated with Seaweeds and Seagrasses. Ohtsuka S, Suzaki, Horiguchi T, Suzuki N, Not F, editor. Marine Protists: Diversity and Dinamics. Tokyo. Springer. DOI: 10.1007/978-4-431-55130-1 25. p.

[16] Satheesh S, Ba-akdah MA, Al-Sofyani AA. 2016. Natural Antifouling Compound Production by Microbes Associated with Marine Macroorganism. Electr J Biotechnol. 21:26-35. doi: 10.1016/j.ejbt.2016.02.002.

[17] Marhaeni B, Radjasa OK, Khoeri MM, Sabdono A, Bengen DG, Sudoyo H. 2011. Antifouling Activity of Bacterial Symbionts of Seagrasses against Marine Biofilm-Forming Bacteria. JEP. 2, 1245-1249.

[18] Nakashima T, Miyazaki Y, Matsuyama Y, Muraoka W, Yamaguchi K, Oda T. 2006. Producing mechanism of an algicidal compound against red tide phytoplankton in a marine bacterium gammaproteobacterium. Appl Microbiol Biotechnol. 73 (3): 684-90.

[19]Lee BK, Katano T, Kitamura SI, Oh MJ, Han MS. 2008. Monitoring of Algacidal Bacterium, Alteromonas sp. Strain A.14 in its Application to Natural Cochlodinium polykrikoides Blooming Seawater Using Flouresence In Situ Hibridization. $J$ Microbiol: 274-282.

[20] Kim D, Kim JF, Yim JH, Kwon SK, Lee CH, Lee HK. 2008. Red to Red - the Marine Bacterium Hahella chejuensis and its Product Prodigiosin for Mitigation of Harmful Algal Blooms. J Microbiol. Biotechnol. 18(10): 1621-1629.

[21] Furusawa G, Yoshikawa T, Yasuda A, Sakata T. 2003. Algicidal activity and gliding motility of Saprospira sp. SS98-5. Canadian J Microbiol. 49(2): 92-100. doi: 10.1139/w03-017.

[22] Kim JD, Kim JY, Park JK, Lee CG. 2009. Selective control of the Prorocentrum minimum harmful algal blooms by a novel algal-lytic bacterium Pseudoalteromonas haloplanktis AFMB-008041. Mar Biotechnol. 11(4): 463-72.

[23] Lundholm N, Moestrup O. 2000. Morphology of the Marine Diatom Nitzschia navis-varingica, sp. nov. (Bacillariophyceae), another Producer of the Neurotoxin Domoic Acid. J Phycol. 36: 1162-1174. doi/10.1046/j.1529-8817.2000.99210.x

[24] Sun XX, Choi JK, Kim EK. 2004. A preliminary study on the mechanism of harmful algal bloom mitigation 
by use of sophorolipid treatment. $J$ Experiment Mar Biol Ecol. 304: 35-49 doi:10.1016/j.jembe. 2003.11.020.

[25] Luo J, Wang Y, Tang S, Liang J, Lin W, Luo L. 2013. Isolation and Identification of Algicidal Compound from Streptomyces and Algicidal Mechanism to Microcystis aeruginosa. PLoS ONE 8(10): e76444. doi:10.1371/journal.pone.0076444.

[26] Li Y, Zhu H, Lei X, Zhang H, Cai G, Chen Z, Fu L, $\mathrm{Xu} \mathrm{H}$, Zheng T. 2015. The death mechanism of the harmful algal bloom species Alexandrium tamarense induced by algicidal bacterium Deinococcus sp. Y35. Front. Microbiol. http://dx.doi.org/10.3389/fmicb. 2015.00992.

\begin{tabular}{|c|c|}
\hline \multicolumn{2}{|l|}{ Abbreviations } \\
\hline EhEd & Enhalus acoroides \\
\hline ThEd & $\begin{array}{l}\text { consortium bacteria } \\
\text { Thalassia hemprichii } \\
\text { consortium bacteria }\end{array}$ \\
\hline BG & $\begin{array}{l}\text { the dinoflagellate which was isolated } \\
\text { from Jakarta Bay when it was blooming } \\
\text { in } 2015 \text { and had not been identified }\end{array}$ \\
\hline IMK Daigos's & : medium for plankton \\
\hline MPC-200 & : Plankton counter \\
\hline$\% \mathrm{AA}$ & : percent of algacidal activity \\
\hline $\mathrm{T}$ & : Treatment growth \\
\hline $\mathrm{C}$ & : Control Growth \\
\hline $\mathrm{t}$ & : the observation period \\
\hline K & control \\
\hline $\mathrm{rP}$ & : treatment \\
\hline
\end{tabular}

